\title{
Stainless Bodies, Tarnished Minds: Race, Slavery, and the Chinese Immigrant Body, 1868-1904 ${ }^{1}$
}

\section{Rune Reimer Christensen}

University of Southern Denmark

\begin{abstract}
This article discusses the commonality of interpretation of Chinese bodies between different schools of thought in American society, which came to understand Chinese immigration in the light of discourses of slavery, bodies, and race. This construal of the Chinese in time transferred to public discourse on other immigrant groups, such as Japanese and to a lesser extent Eastern Europeans, from the 1880 s onwards. The response to the presence of Chinese bodies in American society, then, reflected the limits of cosmopolitanism as well as the racial and bodily barriers around Americanness at the dawn of the 20th century.
\end{abstract}

Keywords: slavery-immigration-race-bodies-Chinese-African AmericansExclusion Act-periodicals-public discourse

In this article construals of the body in the U.S. anti-Chinese immigration debates between 1868 and 1904 are discussed. Interpreting anti-Chinese sentiment not so much as an anti-immigration discourse per se, but as a discourse on slavery, bodies, and race, I argue that commonality of understanding emerged among opponents and supporters of Chinese immigra-

1 An earlier version of this text won the Orm $\varnothing$ verland Prize for best graduate paper delivered at the Nordic Association for American Studies Conference 2009. The author is grateful to the Royal Danish Academy of Sciences and Letters for granting a conference stipend from the Niels Bohr Fund, and thanks Professor Orm Øverland, the NAAS Board, and the faculty of the Center for American Studies, University of Southern Denmark. 
tion, portraying the Chinese in terms of indefatigable foreign bodies and slavish, unamericanizable minds. The major point of contention became the consequences which the presence of Chinese bodies would have for the nation. In a nation not long past the Civil War, the Chinese immigrant body seemed uncomfortably reminiscent of slavery. This body-centered discourse returned time and time again to the Chinese potential for slavery, whether as virtual slaves to, or inadvertent masters of, white Americans.

Viewed in the context of mass migration, the anti-Chinese campaign seems incongruous. ${ }^{2}$ Of the over 20 million registered immigrants arriving between 1868 and 1904, less than 250,000 were Chinese. ${ }^{3}$ The actual number of Chinese in the country at any one time was much lower due to attrition, return migration, etc. Nevertheless, the 'Asiatic' Invasion became a staple of fiction writing, government reports, and the media. Unregulated Chinese immigration began in the late 1840s. The Burlingame Treaty of 1868 established bilateral relations and encouraged immigration, though it expressly denied the right to naturalization. The offer did not stand. Initially the Chinese Exclusion Act of 1882 barred laborers for ten years while allowing for e.g. merchants and students. However, numerous restrictions were introduced after 1882. In 1884 Congress broadened the scope of the Exclusion Act to include all "persons of the Chinese race," irrespective of citizenship or geographical origin. Over the next 20 years the Act was renewed twice, while amendments broadened the definition of "laborer" and retroactively annulled certificates of re-entry held by Chinese residents out of the country. Extended in 1902 to apply to all insular possessions, including Hawaii and the Philippines, exclusion was made permanent in 1904.

The present discussion is based on a systematic study of three prominent periodicals published between 1868 and 1904. ${ }^{4} 152$ sources were identified, most of them lengthy expositions on the Chinese Question. These sources

2 The term "anti-Chinese campaign" is used here in a loose sense, referring to an attitude that was expressed in contributions to periodicals, rather than the organized, labor-led anti-Chinese movement which found its main written expression in newspapers and pamphlets.

3 Table Ad 136-148 in Carter et al., 2006; Chan 1990.

4 The Overland Monthly (1868-1875), resurrected as The Californian (1880-1882), renamed The Overland Monthly (1883-1935); Scribner's Monthly (1870-1881), absorbed second run of Putnam's (1853-1857, 1868-1870), renamed The Century: A Popular Quarterly (though issued monthly; 1881-1939); The North American Review (1815-1939, 1964-). The present article must necessarily rely on a discussion of representative sources rather than the entire corpus. 
have gone largely unutilized in historiography. ${ }^{5}$ The anti-Chinese campaign in periodicals was conducted at a curious remove from the organized, laborled anti-Chinese movement, by those whose interests were mainly academic; however, persons absolutely central to the codification and implementation of anti-Chinese sentiment contributed, such as Senators and Representatives at State and Federal levels, diplomats and immigration officials.

In 1871, one Frank H. Norton characterized the Chinese as "the most industrious, docile, and intelligent servants known." In the early years of the Republic, slavery and occasional immigration from Europe fulfilled the nation's manual labor needs, Norton argued. Now, however, the development of the nation required "intellectual and agricultural labor." The potential deadlock on development by unionized European immigrant laborers could be avoided through the importation of Chinese labor, which would allow for the development of manufacturing plants and agriculture. Another benefit was that the Chinese could subsist on a sparse diet on which "they are capable of prolonged efforts of labor which would put to shame many of our stalwart beefeaters."6

Henry Robinson likewise noted the potential for development in the American West, establishing the necessity of cheap labor: "We cannot subject our own people to a competition with the half-fed, half-clad labor of Europe, and we are therefore compelled to utilize the only equivalent resource at our command," namely Chinese labor. ${ }^{7}$ The white race in America had outgrown the basest labor. The Chinese were racially suited for such work, while white workers in Europe were in a low position due to historical factors rather than racial ones. It was preferable to recruit "mudsills" of "a race which would be benefited by even that position in a civilized society" than to subject "a portion of our own race to a position which they have outgrown."

It appears that the very thing which elevated the Chinese within the hi-

5 See e.g. Aarim-Heriot 2003; Chan 1990; Coolidge 1909; Daniels 1997; Jacobson 2000; Lee 2003: McClain 1994; McClellan 1971; Miller 1969; Sandmeyer 1939; Saxton 1971; Takaki 1979, 1989, 1993. These scholars use at best a handful of sources from periodicals, and do not reflect on the distinct nature of these sources. Literary scholars have, however, analyzed the numerous works of short fiction on Chinese immigrants in The Overland Monthly and The Californian. See Chu 1974; Wu 1982; Frost 2005. Of the eightyone pieces of short fiction published in these two periodicals (1868-1935), sixty-nine were on this subject; Wu 1982,41.

6 Norton, Frank H., "Our Labor-System and the Chinese," Scribner's Monthly, 2/1, May 1871, 61-71.

7 Robinson, Henry, "Our Manufacturing Era," Overland Monthly, 2/3, March 1869, 280-82. 
erarchy of working bodies implied an unsoundness of physiques capable of minimal subsistence and maximum yield; the ability to suppress natural physical needs while laboring strenuously thus was not celebrated as something laudable and meritorious in a laborer, but seems to have been considered a sign of both moral and bodily unsoundness and unnaturalness - as compared with the strong, natural appetites and behavior of the right-minded American workingman.

The two writers did not entirely agree in their analyses of the Chinese condition. Norton felt that while the Chinese were more intelligent than the recently freed slaves, who were "ignorant and brutish as a mass" and in need of direction "by a higher intelligence," nevertheless the Chinese could not aspire to much. The most promising feature of the race was the combined effect of their adaptability to the rigors of the workplace and their "blessed ignorance" of politics and the American mode of government. A disposable caste of workers "[a]ccustomed to be governed," the Chinese were praised as willing to work for far less than Americans, willing to leave when no longer needed, and disinterested in the affairs of the nation. ${ }^{8}$ Conversely, Robinson argued that the Chinese in America as a race did not possess the intelligence to participate in government.

Robinson's and Norton's conflicting views - lack of intelligence versus traditional non-participation - had the same practical implications: that the Chinese could be in the nation, but not of it. These voices, among the most favorable to be found on the subject in the periodicals under scrutiny, were distinctly in the minority. They are of interest here not for their rarity, but for the conceptual basis they share with the anti-Chinese campaign.

On the Chinese Question, the point of departure for most contributors to popular periodicals was one of biology, expressed in terms of race and Chinese bodily capacity. Interrelated notions of, firstly, Chinese biological superiority, in the sense of biological efficiency and endurance rather than racial, cultural, or moral superiority; and secondly, Chinese mental changelessness, were at the heart of American public discourse on this issue. This superiority of the Chinese body, allegedly earned through centuries of oppressive living in overpopulated China, manifested as an ability to survive on far less nourishment and under far worse living conditions than American workers. The Chinese mind resulted from an unchanging social order 
which had bred obedience, exactitude, and strict social standards into the uncountable millions of Chinese. Irving M. Scott concisely expressed this view, claiming that as it had taken seventy centuries of "uniform despotism and slavery" to create the Chinese, it would take seventy more to "eliminate those inherited or constitutional vices." As shown above, the perceived level of intelligence in the Chinese race was sometimes used to measure their capacities for labor and participation in the life of the nation agairist the capacities of another specific group of laborers - former slaves - as well as those Americans performing the duties of citizenship. The Chinese were frequently found to be as optimized for labor as they were considered unsuited and unsuitable for citizenship. From this first tier, the concepts of bodily superiority and mental changelessness, derived a consideration of the economic consequences of Chinese biological properties for the nation. Some replaced or twinned this second tier with a consideration of the moral and cultural implications of Chinese hereditary low morals and alien ways. Finally, referring to the second tier, writers asserted the moral right to exclude the Chinese, for the good of the nation.

In 1877 , inspired by a recently concluded inquiry into the "Social, Moral, and Political Effect" of Chinese immigration by a special committee of the California State Senate, U. S. Senator Aaron A. Sargent (R-CA) introduced to Congress a bill calling for a Senate committee to travel to California and investigate "the character, extent, and effect of Chinese immigration to this country." 10 A House committee soon joined them. Senator Sargent, writing the joint committee's conclusion in the absence of the chairman, argued that it was "painfully evident" to anyone reading the report and the testimony that "the Pacific coast must in time become either American or Mongolian." In order to compete, the white workingman's only option was to "work so cheaply that the Chinese cannot compete with him, for in the contest for subsistence he that can subsist upon the least will last the longest."

But to descend to the Chinese level was virtually impossible, for they were endowed with "revolting characteristics." It was furthermore evident that "[t]he American race is progressive and in favor of a responsible representative government. The Mongolian race seems to have no

9 Scott, Irving M., "Protection to American Labor," Overland Monthly, 8/46, October 1886, 409-419.

10 Report of the Joint Special Committee to Investigate Chinese Immigration. 44th Congress, 2nd Session. Report no. 689, (1877, reprint), iii. 
desire for progress, and to have no conception of representative and free institutions." 11

Generally agreeing that the Chinese as a race were in a state of arrested development, participants in public discourse disagreed about the implications for the United States, should their immigration continue. Charles Wolcott Brooks, for many years Japanese Consul in San Francisco and a self-described frequent visitor to China, wrote that the main use of Chinese in the United States was as "hewers of wood and drawers of water" under white supervision. The task before the nation was to become masters of the situation and "direct a system furnishing us with Asiatic laborers" in order to elevate such members of the white working classes as were capable of improvement. To Brooks, then, Chinese immigration seemed to be a matter of national (white) self-improvement. The Chinese could serve the nation, but were not qualified to be of it. This was essentially the argument put forth by Norton and Robinson. If the Chinese were encouraged to come, Anglo-Saxon immigration should be equally encouraged in order to maintain equilibrium. They were able to "live, save, and thrive on wages far below our laborers." However, despite being "intelligent," the Chinese were only capable of limited improvement. ${ }^{12}$

Summoned before the California State and Joint Congressional Committees in 1876, Brooks had the opportunity to expand on his views. Comparing the Chinese to a group familiar to the Joint Committee, the African Americans, Brooks once more argued the biological origin of Chinese difference. Excepting "neat mulattos who have white blood," the Chinese were biologically and culturally superior to African Americans, and consequently less easily assimilated. African Americans were easily taught and therefore suited for assimilation and capable of progress under supervision, but the Chinese, while having "a great deal more brain power than the original negro," (but not more than partially white persons) were in a state of arrested development: "their form of civilization has crystallized, as it were." ${ }^{13}$ Californian novelist and travel writer Thomas J. Vivian succinctly

11 Report of the Joint Special Committee, 1877, iv-vi.

12 Brooks, Charles Wolcott, "The Chinese Labor Problem," Overland Monthly, 3/5, November 1869, 407419.

13 Brooks' testimony in the Report of the Joint Special Committee, 1877, 941-951. This point was also made by Henry George, founder of the single-tax or Georgist movement: "[the Chinese] are like the negroes [...] up to a certain point they learn very fast, but beyond that point it is very difficult for them to go [...] they are incapable of attaining the state of civilization the Caucasian is capable of." George was conflating cultural 
expressed the dichotomy of the perceived concurrent Chinese inferiority and superiority. They were inferior to the Anglo-Saxon in the hierarchy of races, but, paradoxically, absolutely superior in the marketplace for reasons of their racially imparted characteristics. ${ }^{14}$

In raising the issue of blood, Brooks was well within the paradigm of the nineteenth-century vocabulary of race on which the anti-Chinese campaign drew heavily. At the heart of the nineteenth-century concept of the uniqueness of American political institutions lay a strict racial hierarchy which divided mankind according to aptitude for self-government and cultural and technological progress. According to John Higham, in England and America two traditions of thoughts about race gradually merged over the course of the nineteenth and early twentieth centuries. Inspired by the romantic aesthetic movement, racial nationalists emphasized culture as ancestry and the permanence of nationality in a self-congratulatory description of the eminence of Anglo-Saxondom, then a vague cultural concept. Racial naturalists, on the other hand, focused on physical differences in other races, and associated those differences with cultural inferiority. ${ }^{15}$ Influenced by the growth of nationalist thought in the nineteenth century, naturalists increasingly divided Europeans into biological types. Nationalists on their part gradually "absorbed biological assumptions about the nature of race" until "every national trait seemed wholly dependent on hereditary transmission." "16 According to Thomas F. Gossett the notion of Anglo-Saxon supremacy developed between the 1840s and the Spanish-American War of 1898, from expressing an emotive pride in the uniqueness of American political institutions to constituting a pervasive scientific theory of white racial superiority. ${ }^{17}$ The definition of whiteness, crucial to American interpretations of race and hence to the anti-Chinese campaign, was ever in flux. Matthew Frye Jacobson has shown that the definition of 'white' steadily expanded through the nineteenth century and the early twentieth centuries. A notion of variegated whiteness held sway from the $1840 \mathrm{~s}$ until the $1920 \mathrm{~s}{ }^{18}$ One might imagine a ladder with blacks on the lowest rung, Asians above

stagnation with hereditary changelessness. Report of the Joint Special Committee, 289. The Joint Congressional Committee elected to include Brooks' 1869 article as an appendix (1215-1224) to its Report.

14 Vivian, Thomas J., "John Chinaman in San Francisco," Scribner's Monthly, 12/6, October 1876, 862-872.

15 Higham 1992, 131-157.

16 Higham 1992, 133-134.

17 Gossett 1997 (1963) 310-311.

18 Jacobson 1998, 68-90 passim. Also Kolchin 2002; Roediger 1999(b). 
them, followed by a progression of increasingly whiter (if still inferior and not all that white) races of Europe. The highest rung was occupied by the Anglo-Saxon. This analysis was based on skin color as well as the perceived mental and physical traits belonging to each individual race.

Race was not an absolute but a relative concept, nor was the notion of racial superiority resolute. In these periodicals, the concepts of the biological superiority and hereditary changelessness of the Chinese race were often set at odds with perplexed comments about the "self-evident" superiority of the American race, the white race, or the Anglo-Saxon race, which nevertheless did not appear strong enough to compete. ${ }^{19}$

The Chinese Question was not a singular discourse, for considerations of the qualities of other immigrant groups drew upon the ideas regarding racial ability to partake in the nation which were invested in the Chinese Question. Wrote one self-identified Anglo-Saxon in 1883,

The Chinese Question might rather be called the Immigration Question, for the principles underlying it are general and not special in character. It only happens that the Chinese immigration, for the first time in the history of the country, seriously calls up for consideration these principles. ${ }^{20}$

By “Immigration Question," however, the writer evidently meant the "Race Question," for the preconditions for rightful immigration were cast in terms of race familiar to observers of the anti-Chinese campaign. Total assimilation of immigrants was necessary for the survival of a free republic. This entailed absolute loyalty as well as participation in the life of the nation, for there could be no divided allegiance. However, only certain races of the world seemed "capable of developing [...] the capacity for a representative government." Some races, such as the "Asiatic," tended naturally towards "despotism." Of all the Indo-European peoples, only the Germanic peoples showed a marked capacity for self-government; and of those, only the Anglo-Saxons had "developed the capacity to the highest capacity." 21 It also meant assimilation into the "great body of the people" in a literal sense. But blood did not mix well. Mixing the blood of Anglo-Saxons with that of lesser races unfit for self-government would invariably result in progeny

19 Bonner, John, “An Empire in Ruin,” Overland Monthly, 15/86, February 1890, 172-180.

20 Widney, J. P., "The Chinese Question," Overland Monthly, 2/12, Dec 1883, 627-631.

21 Widney, op, cit. 
whose capacity for it would be greatly decreased. For most participants in public discourse on immigration, a lack of aptitude for self-government was a given with non-European peoples. "We all admit," wrote one contributor to the North American Review in 1879,

that particular races, the Asiatics for example, are not yet fit for it. We interpret this capacity by assuming that they are not sufficiently advanced on the road to perfection. Quite possibly these peoples may never advance along that road, and have no need to advance. All men require to be governed, either by themselves or others." ${ }^{22}$

Race, then, determined capacity for self-government. Hence, race also determined suitability for Republic-bound migration, which was often cast in bodily terms. If Brooks in speaking of "partially-white mulattos" invoked a reverse one-drop rule whereby 'white' blood uplifted persons of mixed race, blood mixing was nevertheless considered a net loss for the white race. The metaphor of blood mixing could be applied to the act of immigration itself. Chinese immigrants were likened to "blood-poisoning," in the sense that they constituted an isolated, "foreign substance" in the body politic, as contrary to benign immigration, the "life-blood of young nations," as Thomas J. Vivian put it. ${ }^{23}$ New England minister Theodore Thornton Munger, a prominent figure in the Social Gospel movement, made similar points about the Chinese race poisoning the nation. Exclusion should be enforced against any group not ready to enter harmoniously into the nation, Munger argued. All national problems, except the 'Negro problem,' were caused by the immigration of inferior races, whose amalgamation with Americans in the past had caused one fifth of the blood currently in the nation's veins to be "defective in political capacity." 24 John F. Miller, in a lengthy diatribe published in the Californian in April of 1880 , which reads

22 Froude, James Anthony, "Romanism and the Irish Race in America, Part I," North American Review, 129/277, 519-537, December 1879. The comment about Asians was made in relation to Irish immigrants, whom the author considered to be of a foreign race governed by the Roman Catholic Church. They could not be assimilated, a process which would in any case be undesirable for American society, and were incapable of self-government, in part because Roman Catholicism was such an ingrained part of their hereditary condition.

23 Vivian, Thomas J., "John Chinaman in San Francisco," Scribner's Monthly, 12/6, October 1876, 862-872.

24 Munger, T.T., "Immigration by Passport," The Century, 35/5, March 1888, 791-799. As late as 1929, the Daughters of the American Revolution and the American Legion took out a series of advertisements in the Washington Post warning against those who would oppose the National Origins Act in order to admit nonEuropean immigration and thereby "play politics with the nation's blood stream." Ngai 1999, 68 . 
like the announcement of a policy position for his successful run for a U.S. Senate seat (Republican) that year, likewise used blood imagery: "It is in the blood. There can be no mixture of the blood with the Caucasian, without the deterioration of the latter race." 25

Dramatic imagery aside, the "blood" argument was partly a version of the argument on the Chinese hereditary cultural condition and consequent immiscibility with Americans. But it also opened a line of argument claiming that the perceived cultural immiscibility of the Chinese resulted from biology. Senator Sargent also made this point in the Congressional report: "there is not sufficient brain capacity in the Chinese race to furnish motive power for self-government." 26

Representative Edwin R. Meade (D-NY), a member of the joint committee and author of a 1877 conference paper on the Chinese Question which had been published in the California report, concurred: "Ethnologists declare that a brain capacity of less than 85 cubic inches is unfit for free government, which is considerably above that of the coolie as it is below that of the Caucasian"27

The Chinese were, ipso facto, unable to embrace the institutions and ideals of a free republic. Meade warned that due to the principles recognized in the Naturalization Act of 1870, irrespective of current treaties and the permanent status of Chinese mental capacity, the Chinese must eventually be granted naturalization and the vote. If they were not, a new caste system of degraded Chinese laborers, not unlike the "abomination of slavery" would result. ${ }^{28}$

The concept of slavery played an important, multifaceted role in the discourse regarding Chinese immigrants. In public discourse, slavery neatly represented the twin aspects of the racial threat notion from which Exclusion arguments derived. The Chinese neither would nor could adapt to conditions in the United States. The American must either be displaced by or

25 Miller, John F., "Certain Phases of the Chinese Question," The Californian, 1/3, March 1880, 237-242 (Reprinted: Overland Monthly, April 1886, 422-428).

26 Report of the Joint Special Committee, 1877, vi.

27 Meade, Edwin R., "The Chinese Question: Annual Address to the Social Science Association of America, Saratoga, New York, September 7, 1877," reprinted as 293-302 in: California State Senate Special Committee on Chinese Immigration, Chinese Immigration. Its Social, Moral, and Political Effect. Report to the California State Senate of its Special Committee on Chinese Immigration. Sacramento: F.P. Thompson, 1878.

28 Meade 1877. 
adapt to the Chinese presence by descending to their level; but in adapting, he would have to surrender his dignity as a free workingman, any chance of supporting a family, and, in the process, that which made him unique among all the races of the world: his capacity for self-government.

J.P. Widney, whose greatest concern was the consequences of racial mixing for the maintenance of frec government, boiled down the Chinese Question to four options. Allowing free racial mixing, until either the Chinese or the Americans were subsumed as a race; naturalizing the Chinese, but keeping them racially separate; denying the Chinese both citizenship and interracial mixing, but allowing them to stay in the United States; or practicing exclusion. Mixing, Widney argued, would destroy the Anglo-Saxon race and the free republic, as would naturalization, by allowing a non-assimilable and hereditarily incompetent race to form voting blocs, to the detriment of the nation. Denying citizenship and avoiding miscegenation would bring about the low caste of laborers feared by Meade, inevitably leading to revolution - it was "only a question of numbers" before trouble began. But the fourth option, Chinese Exclusion, "settles all controversy."

A disagreement over the significance of numbers interacted with the core concepts of the anti-Chinese campaign. Regarding racial degradation through amalgamation, the introduction of any Asian blood was thought to damage the vitality of the Anglo-Saxon race. Also on the issue of self-government numbers were immaterial up to a point, for racial mixing would impair the political and other racial capabilities of the Anglo-Saxon nation, while non-assimilation - allowing the Chinese to enter the nation's blood stream, as it were, but not those of its citizens - would cleave the political union in twain, half slave and half free. But in terms of the postulated destruction of the white working class by Chinese immigrants, numbers mattered. If the actual volume of Chinese immigration to the U. S. was minor, the potential immigration haunted contributors to periodicals during the last part of the nineteenth century. The Chinese were thought able to overrun the Pacific Coast by sheer numbers, for China could "spare a hundred million and scarcely improve her ventilation." ${ }^{29}$ Senator Sargent stated, following the Rock Springs Massacre of Chinese miners in Wyoming, that no matter how many times the Chinese "crowded" into an island or nation, and no matter how many times they were "massacred" by "native races" in 
which the Chinese invariably engendered great hostility, more would come. Filling dead men's shoes, the "invasions" would go on "until resistance was futile." 30

Representative Thomas Geary (D-CA), author of the 1892 Geary amendment to the Exclusion Act, linked exclusion to opposition to slavery: "[T]oday we have the exhibition of another race as absolutely enslaved by their masters as were the negroes in the South, establishing themselves and their institutions in our midst." 31

The masters referred to were the Six Companies, powerful mercantile and social organizations from the six provinces of southeastern China from which most of the immigrants hailed. Similarly, San Francisco Mayor James D. Phelan on several occasions argued that the Chinese were de facto slaves, and that their immigration was orchestrated by the Six Companies. Few came voluntarily. "Of such stuff citizens fit for a republic cannot be made," Phelan asserted..$^{32}$ Chinese in the free republic were "masquerading as free men, while they bear every characteristic of slaves." Irving M. Scott claimed that African slavery was involuntary and partial, whereas "Chinese slavery is a normal condition of the mass of that people." 33

Defining slavery differently, as "the slow but sure process which befalls an inferior race or people commingled with or settled among a superior race," James O'Meara argued that the U. S. should not "entice or allow a race here to be made slaves, or to become subject to slave conditions." 34 "If we are to have them at all," H. Latham wrote, "we must have them as they are in China," with "every objectionable feature of their social and domestic life." ${ }^{35}$ Imprinted upon the Chinese mind was a hierarchical system of enslavement, descending from the Emperor and encompassing the entire race. In America this "peculiar institution" meant that the Chinese remained "unchanged and unchangeable." Using the euphemism for the enslavement of African Americans was a very suggestive choice of words when used in the context of the alleged involuntary migration to America

30 Sargent, A. A., "The Wyoming Anti-Chinese Riot," Overland Monthly, 6/35, November 1885, 507-512; Sargent, A. A., "The Anti-Chinese Riot-Again," Overland Monthly, 7/37, January 1886, 54-60.

31 Geary, T. J., "Should the Chinese Be Excluded?", North American Review, 157/440, July 1893, 58-68.

32 Phelan, James D., "Why the Chinese Should Be Excluded," North American Review, 173/5, November 1901, 663-676; Phelan, James D., "Chinese Question," Overland Monthly, 7/39, March 1886, 328-329.

33 Scott, Irving M., "Protection to American Labor," Overland Monthly, 8/46, October 1886, 409-419.

34 O'Meara, James, "The Veto Power and the Chinese," The Californian, 5/30, June 1882, 549-556.

35 Latham, H., "Chinese Slavery," Overland Monthly, 3/2, February 1884, 175-178. 
of a group deemed to be hereditarily and socially pressed into slavery, even into accepting slavery.

If the abolition of African-American slavery was a patriotic act, safeguarding the nation from "the evil of Asiatic slavery, and our American labor from the unjust and degrading competition" presented by the Chinese was no less of an act of patriotism. "Protection against such competition," Geary wrote, meaning Chinese labor, was not only advisable but necessary to remaining a free republic. But the enslavement of the Chinese was more than just a practical arrangement by a particular group of merchants. "Slavery" in the Chinese race was rendered as a spiritual condition resulting from their non-participation as citizens in the life of the nation, which again was due to their inferior condition.

Support for Exclusion, then, could be cast in terms of opposition to slavery, but there was one more aspect to it. The belief that all immigration brings increased and even unfair labor market competition is not particular to the anti-Chinese campaign of the late nineteenth century, but is endemic to the history of immigration. As E. W. McGraw put it, all immigration brought the same kind, if not the same degree, of labor market competition. Thrifty British immigrants also posed a danger to the white American workingman, for they could afford to take lower wages than Americans and still improve their own situation, compared to wages back home. ${ }^{36}$ But the Chinese were formed by "grinding pressures of centuries of poverty" to the point where economic habits of living had become second nature. "The Chinese can and do live on less money than any of the races called white," McGraw maintained. As a result of the Chinese capacity for marginal living, "whenever Chinese labor comes into contact with white labor, the latter goes to the wall." Therein lay the danger. European immigrants, be their condition ever so lowly, were racially disposed for bettering themselves, and were not as suited as the Chinese for mean survival. They were not thought to become like slaves in the American labor market; nor were Americans bound to become as slaves under the labor-market conditions which European immigration created. But such was the nature of the Chinese that they would either become subject to virtual slavery by virtue of their mentality, or come to impose it upon others by virtue of their bodily mean survival skills.

36 McGraw, E. W., "Immigration as an American Question," The Californian, 5/27, March 1882, 270-279. Other examples include Anon., "Current Comment," Overland Monthly, 1/1, January 1883, 94-99; Anon., "Etc.," Overland Monthly, 9/54, June 1887, 659-662. 
The fundamental difference between American laborers, capable of exercising their rights and duties in a free republic, and Chinese coolies, was a matter of bodily constitution, the California State Senate report noted: white men required meat and bread, whereas the Chinese required nothing more than rice, dried fish, and tea. Bodily and mentally adapted to slave-like conditions, the Chinese threatened to defeat the Anglo-Saxon. To survive bodily in the face of Chinese competition, the white workingman "must be entirely changed in character, in habits of life, in everything the Republic has hitherto required him to be." ${ }^{37}$ As Senator James G. Blaine (R-ME), a vigorous opponent of Chinese immigration, argued during the introduction of the Fifteen Passenger Bill of 1879, "men who must have meat and bread" cannot work alongside a man who can live on rice. The result would invariably be to bring down the "beef-and-bread man" to rice standard, not raise the minimum. Slavery had debased free labor and throttled the South; the Chinese race, whose labor was even worse than slavery, would "throttle and impair the prosperity" of the Pacific Coast. ${ }^{38}$

The perception of the Chinese as physically superior and mentally changeless was not limited to opponents of Chinese immigration. Several proponents of Chinese immigration, such as Norton and Robinson, embraced it. The year before the Exclusion Act was passed, Frederick Douglass used the vocabulary of white anti-Chinese discourse to illustrate the hypocritical nature of white racial discourse:

Our Californian brothers, of Hibernian descent, hate the Chinaman, and kill him, and when asked why they do so, their answer is that a Chinaman is so industrious he will do all the work, and can live by wages upon which other people would starve. When the same people and others are asked why they hate the colored people, the answer is that they are indolent and wasteful, and cannot take care of themselves. ${ }^{39}$

37 Italics added for emphasis. Report of the California State Senate Special Committee, 47.

38 The Fifteen Passenger Bill, vetoed by President Hayes as a breach of the Burlingame Treaty, sought to stem immigration by limiting the number of Chinese passengers on any one ship.

39 Douglass, Frederick, "The Color Line," North American Review, 132/295, June 1881, 567-578. Revisiting the theme five years later during the peak of the debate on the Chinese Question in American periodicals, but in the context of the future of African Americans, Douglass seemed to partially abandon the notion of a specific ethnic group (the Irish) being at fault, in favor of a wider notion of white racial responsibility, as had already been offered in that discussion of African Americans: "[S]ometimes I have feared that, in some wild paroxysm of rage, the white race, forgetful of the claims of humanity and the precepts of the Christian religion, will proceed to slaughter the negro in wholesale, as some of that race have attempted to slaughter Chinamen, and as it has been done in detail in some districts of the Southern States. The grounds of this fear, however, have in some measure decreased, since the negro has largely disappeared from the 
Douglass carefully rejected the arguments of the anti-Chinese campaign even as he had to employ its vocabulary to remain within the discourse, but other supporters of Chinese immigration clearly adopted the anti-Chinese racial insights. This was true even in the mid-1880s after the issue had seen much public debate. "They seem to be of a separate and foreign race," one supporter wrote in 1884, "wedded to habits, to customs, to social institutions, and to a religion peculiarly their own, so thoroughly ingrafted [sic] into their mental organization by a long succession of ages as to have become now a part of their very natures., 40

William Blackwood's article in fact embraced the views of the anti-Chinese camp to an astonishing degree. It is curious to observe that, barring a few voices of opposition in the pro-Chinese camp, participants in the public discourse almost entirely agreed on the basic premises for the discussion, disagreeing only on the practical implications thereof. In many ways Blackwood was writing in the tradition of early supporters of the Chinese on economic grounds, such as Norton and Robinson. Exclusion was in violation of sound principles of political economy. A labor force was not available which would take up the labor in California orchards on Chinese terms, terms which were strikingly similar to those of the feudal peasantry of Europe: having no voice in government, and not aspiring to callings above that of laborer. Here the writer touched obliquely upon the fundamental issue of self-government. A replacement labor force would have to be recruited from the cities of Eastern states or from tenant farmers in Europe. But the former had proved inadequate to the task, and the Europeans, though brought over on terms of tenant farming, would quickly become masters. Strikes would ensue and demands would be made at critical moments until the vineyards were held by the former tenants. In possessing this drive towards self-betterment and self-government, Blackwood seemed to be saying, even the lowliest classes of Europe were different from the Chinese. The latter were

arena of Southern politics, and has betaken himself to industrial pursuits and the acquisition of wealth and education, though even here, if over-prosperous, he is likely to excite a dangerous antagonism; for the white people do not easily tolerate the presence among them of a race more prosperous than themselves. The negro as a poor ignorant creature does not contradict the race pride of the white race. He is more a source of amusement to that race than an object of resentment." Douglass, Frederick, "The Future of the Colored Race," North Americun Review, 142/354, May 1886,437-441. Douglass may have been referring to the Washington and Wyoming anti-Chinese riots of 1885 .

40 Blackwood, Wm. C., "A Consideration of the Labor Problem," Overland Monthly, 3/5, May 1884, 449460 . 
"born to servitude-it has become ingrained in their natures. They never seek to rise above it." But this was laudable, for "it is exactly for menial labor that we desire them."

The concept of changelessness was often challenged by the most proChinese writers such as the former Minister to China, George F. Seward, who argued that, in America at least, the Chinese were very adaptable. This praise was nevertheless couched in terms of race. Seward posited a connection between the Chinese racial virtue of adaptability and Chinese free labor in the United States, but conceded that Chinese immigrants to other countries were "coolies." Edward Burlingame, the son of the author of the Burlingame Treaty, posited the same distinction between the Chinese in America and their "coolie" brethren in Peru and the West Indies. ${ }^{42} \mathrm{~A}$ great deal of confusion furthermore arose concerning the relationship between the notion of changelessness as a racial characteristic and the allegedly coerced or enslaved nature of Chinese labor in the United States and elsewhere.

Paradoxically, American construals of Chinese changelessness were themselves adaptable. A notion of class frequently influenced public views on the Chinese. This is evident in the stipulations of the Exclusion Act, but also from the pains certain contributors took to differentiate between Chinese laborers, or a specific subset thereof, and the Chinese in general. It was no coincidence that one of the major controversies in this context was whether the "depraved" or "coolie" class of Chinese laborers happened to be identical only with the class of Chinese laborers present in the United States. Introducing a note of doubt, Representative Meade allowed that his remarks on the Chinese biological capacity for self-government "do not always apply to the Chinese of the higher caste, who display mental and physical evidence of the infusion of Tartar blood." ${ }^{43}$ The coolie, however, bore "the stamp of "finished'," having reached "the highest attainment of their capacity" thousands of years ago. ${ }^{44}$ Further to this point, Meade argued that "the term 'Chinese Question' is in itself an error," because it only applied to

41 Seward, George F., "Mongolian Immigration," North American Review, 134/307, June 1882, 562-578.

42 Burlingame, Edward L., “An Asiatic Invasion,” Scribner's Monthly, 13/5, March 1877, 687-694. Drawing upon that figure of authority to put some weight behind his argument, Edward Burlingame carefully stated that "of [Mr. Anson Burlingame]'s opinions the writer does not speak without full knowledge" (694).

43 Meade $1877,298$.

44 Meade $1877,297-298$. 
the particular class of immigrants to the United States. "The madarin [sic] or office-holder, and the merchant," rarely seen in America, constituted the other classes. The "Coolie Question" would therefore be a more appropriate title. ${ }^{45}$ Meade's definition of "class," however, is close to that of "race": a strictly racial explanation is offered for the existence of better classes of Chinese, e. g. the mandarins and merchants of "Tartar" blood.

Mcade's note of doubt concerning an identification of the "Chinese race" with more respectable classes who happened to be Chinese struck a chord with lawmakers and immigration officials, as with many contributors to the periodicals. According to George F. Seward, the former Minister to China, Mandarin-class Chinese converts to American religion and "the progressive tendencies of our civilization" who remained in China left nothing to be desired. ${ }^{46}$ Chinese lack of assimilation in the United States was caused by the American refusal to allow it. However, though otherwise a great champion of the Chinese, Seward noted with distaste the immigration of the "coolie classes" to South America. Between Seward's upper-class Chinese in China adapting to American civilization and the coolies who immigrated elsewhere lay a great unmentioned mass of Chinese laborers who had immigrated to the United States. From Seward's description it seems that Chinese adaptability and free labor were contingent upon their class, their mode of emigration and their destination, rather than on inherent Chinese qualities. Seward was placing the transformative power of American society above any inherent capacity or willingness for change possessed by the Chinese. James O'Meara similarly lamented the replacement of the "higher" classes of Chinese - merchants, graduates of Hong Kong's academies - who were the first arrivals in the 1840s and early 1850 s, by hordes of "coolies, "unfit for citizenship as a race." ${ }^{47}$ The differences between O'Meara's descriptions of high-caste and low-caste Chinese are illuminating. The praise for the high castes was pushed aside and replaced with the standard vitriol of the anti-Chinese campaign. The Chinese had overrun the Pacific Coast, had usurped every vocation where cheaper wages gave them an advantage, driving white men to crime and white women to prostitution. The better class of Chinese never emigrated (anymore, presumably), and the "great mass of Chinese who come here are the lowest and vilest of their 
race." In the end, however, the differences between classes were perhaps not so great. "What they were, some of us can still recall," O'Meara said of the first arrivals, "or at least what they seemed to be. What they [the current immigrants] are, we all sorrowfully realize. They are not qualified for citizenship as a race." The inherent features of the Chinese race as a whole trumped apparent differences of class.

Gauged by these periodicals it would appear that the reading public's furor was mostly spent at the turn of the century. The Acts of 1902 and 1904, banning the Chinese for perpetuity, were not mentioned even once in the periodicals. The 3000-delegate strong Chinese Exclusion Convention of 1901, convened in November by the Board of Supervisors of San Francisco to lobby for the continuation of the Geary Act in the name of "Home, Country, and Civilization," was mentioned only by James Phelan, who, as mayor, headed the Convention. ${ }^{48}$ In American periodicals, talk of labor and race issues in an Asian or Pacific context turned toward the relative merits of Chinese workers in the Panama Canal, then under construction, the annexation and industrialization of the Philippines, the Chinese presence in the Pacific, and the best American policy towards China in the interest of trade and an American stake in the game of the Great Powers.

However, the discourse on Chinese bodies got a new lease on life with the anti-Japanese and anti-European immigration discourses of the early to mid twentieth century. The Exclusion Act, banning immigration based on racial or geographical origins, became the baseline for most of the copious (anti-)immigration legislation over the next 80 years, and was reflected in the 1917 immigration act, which denied entry to immigrants from the Asia-Pacific Triangle. The body-oriented public discourse on the Chinese was recycled with regard to many other groups of European and Asian immigrants arriving as part of the New Migration starting in the 1890s. While the legal whiteness of European immigrants under the Naturalization Act of 1870 was never challenged, doubts remained as to their suitability for life in the nation. The rhetoric of the anti-Chinese campaign was for instance employed against Hungarian immigrants, then very novel to the United States, as early as the $1880 \mathrm{~s}^{49}$ One of many successive editors of the Overland Monthly noted that if the candidates running for president in 1884 gave in to

48 McClellan 1971, 14; Lee 2003, 33, 45-47. Phelan, James D., "Why the Chinese Should Be Excluded," North American Review, 173/5, November 1901, 663-676.

49 Roediger \& Barrett 2002, 138-169. 
the demands of labor, very soon the United States would be found gravely asserting that "the oppressed of all nations have a natural right to our soil, except Chinese and Hungarians" $" 50$ and that if this was allowed, the assertion would be made that "“Mongol,' 'Turanian,' 'Tartar"” or whichever designation might be applied to the "blood" shared by Chinese and Hungarians, was by nature a disqualifier for residency in the United States. The editor, by conflating Hungarians and Chinese in this way, was likely referring to the fact that the two groups were considered to share a racial connection via the Hun invasions of Eastern Europe in the fifth century and the Mongol invasions in the thirteenth century. ${ }^{51}$ Senator Sargent, for one, likened Chinese immigration to "countless hosts, like the swarms of Attila." 52 Not surprisingly, "Mongol" or "Mongolian" was commonly used as an alias for Chinese in periodicals. The argument against the Hungarians, the editor of the Overland warned, might then be stretched to argue that the blood of Polish or Russian Jews was "incapable of partaking in free institutions." In the end, exclusion would be enforced against every group that enough people clamored to oppose, until such a time when all immigration ended.

The editor was not the only one drawing on this perceived connection between undesirable Europeans and Chinese. The arguments offered by Arnold White in 1904 against Jewish immigration from Eastern Europe and Imperial Russia to the U.S. and England read like a carbon copy of arguments against the Chinese immigrant body, as did James Phelan's antiJapanese rhetoric when running for Congress in 1914 and $1920 .^{53}$ In the North American Review, Representative Henry Cabot Lodge (R-MA) had, in 1891, approvingly quoted the American consul in Budapest on the issue of immigration from the Austro-Hungarian Empire: "[T]hese slovacks [sic] are not a desirable acquisition for us to make, since they appear to have so many items in common with the Chinese." 54 The response to the presence

50 Anon., "Etc.," Overland Monthly 4/23, November 1884, 553-556.

51 William F. Wu $(1982,9-11)$ explores this connection in nineteenth-century Western popular culture and literature, and argues that medieval interpretations of the Mongol invasion (unbeatable, great numbers, and heathen) are very similar to and may have predicated Californian responses from the 1850 s onwards. Cf. McClellan 1971, 231-234.

52 Sargent, A. A., "The Wyoming Anti-Chinese Riot," Overland Monthly, 6/35, November 1885, 507-512.

53 White, Arnold, "the Jewish Question: How to Solve It," North American Review, 178/1, January 1904, 10-24; Phelan, James D. "The Japanese Evil in California," North American Review, 210/1, January 1919 , 323-328.

54 Lodge, Henry Cabot, "The Restriction of Immigration," North American Review, 152/410, January 1891, 27-37. 
of Chinese bodies in American society, then, reflected the limits of cosmopolitanism as well as the racial and bodily barriers around Americanness at the dawn of the 20th century. 


\section{Works Cited}

Aarim-Heriot, Najia, Chinese Immigrants, African Americans, and Racial Anxiety in the United States, 1848-82, Urbana: Illinois University Press, 2003.

Carter, Susan, et.al., Historical Statistics of the United States: Earliest Times to the Present. Millennial Edition. Vol. One: Population, Cambridge: Cambridge University Press, 2006.

Chan, Sucheng, "European and Asian Immigration into the United States in Comparative Perspective, 1820s to 1920s," 37-75 in: Virginia Yans-McLaughlin (ed.), Immigration Reconsidered: History, Sociology, and Politics, Oxford: Oxford University Press, 1990.

Chu, Limin, The Images of China and the Chinese in the Overland Monthly, 1868-1875, 1883-1935, San Francisco: R\&E Research Associates, 1974 (orig. dissertation, Duke University, 1964).

Coolidge, Mary Roberts, Chinese Immigration, New York: Henry Holt \& Company, 1909 (reprinted 1969 by Arno Press, New York).

Daniels, Roger, "No Lamps Were Lit for Them: Angel Island and the Historiography of Asian American Immigration," Journal of American Ethnic History, 17/1 (Fall 1997), 3-18.

Frost, Linda, Never One Nation. Freaks, Savages, and Whiteness in U.S. Popular Culture, 1850-1877, Minneapolis: University of Minnesota Press, 2005.

Gossett, Thomas M., Race: The History of an Idea in America, $2^{\text {nd }}$ edition, New York: Oxford University Press 1997 (1"st ed. 1963).

Higham, John, Strangers in the Land. Patterns of American Nativism, 1860-1925, New Brunswick: Rutgers University Press, 1992 ( $1^{\text {st }}$ ed. Rutgers University Press, 1955).

Jacobson, Matthew Frye, Whiteness of a Different Color. European Immigrants and the Alchemy of Race, Cambridge: Harvard University Press, 1998.

— Barbarian Virtues: The United States Encounters Foreign People at Home and Abroad, 1876-1917, New York: Hill \& Wang, 2000.

Kolchin, Peter, "Whiteness Studies: The New History of Race in America," Journal of American History, 89/1, June 2002, 154-173.

Lee, Erika, At America's Gates: Chinese Immigration During the Exclusion Era, 1882-1943, Chapel Hill: the University of North Carolina Press, 2003.

McClain, Charles J., In Search of Equality. The Chinese Struggle against Discrimination in Nineteenth-Century America, Berkeley: University of California Press, 1994.

McClellan, Robert, The Heathen Chinese. A Study of American Attitudes towards China, 1890-1905, Columbus: Ohio State University Press, 1971.

Miller, Stuart Creighton, The Unwelcome Immigrant. The American Image of the Chinese, 1785-1882, Berkeley: University of California Press, 1969.

Ngai, Mae M., "The Architecture of Race in American Immigration Law: A Reexamination of the Immigration Act of 1924," Journal of American History, 86/1, June 1999, 67-92.

Roediger, David R., "The Pursuit of Whiteness: Property, Terror, and Expansion, 17901860," Journal of the Early Republic, 19/4, 1999(b), 579-600.

Roediger David R. \& James Barrett, 'In between Peoples: Race, Nationality, and the 'NewImmigrant' Working Class," 138-169 in: Roediger, David, Colored White. Transcending the Racial Past, Berkeley: University of California Press, 2002.

Sandmeyer, Elmer C., The Anti-Chinese Movement in California, Urbana: University of Illinois Press, 1991 (orig. 1939).

Saxton, Alexander, The Indispensable Enemy. Labor and the Anti-Chinese Movement in California, Berkeley: University of California Press, 1971.

Takaki, Ronald, Strangers from a Different Shore. A History of Asian Americans, New York: 
Penguin Books, 1990(a) (orig. Little, Brown \& Company, Ltd., 1989).

, Iron Cages. Race and Culture in $19^{\text {th }}$-Century America, New York: Oxford University Press, 1990(b) (orig. New York: Knopf, 1979).

— A Different Mirror. A History of Multicultural America, Boston: Little, Brown and Company, 1993.

Wu, William F., The Yellow Peril: Chinese Americans in American Fiction, 1850-1940, Hamden: Archon Books, 1982. 